\section{Changes in the Size of Egg-form Embryos with the Advance of Development in the Salamander Hynobius nigrescens}

\author{
HISASHI TAKAHASHI AND \\ HISAAKI IWASAWA
}

\begin{abstract}
Using the eggs derived from 16 females of Hynobius nigrescens, changes in the size of developing egg-form embryos (from 2-cell embryo to gastrula) were studied. No significant difference in the proportional increase in size was found among the embryos of any of the females examined. Conversion factors for obtaining the initial egg size from the size of egg-form embryos were presented.
\end{abstract}

Key words: Caudata; Hynobius nigrescens; Hynobius lichenatus; egg-form embryo; egg size; ontogenic increase

Amphibian embryos that maintain an egg-like appearance during the earlier periods of development are subject to size changes (Løvtrup, 1960). Collecting uncleaved urodelan eggs in the field is rather difficult. It is therefore necessary to make a correction in measured values when the uncleaved egg size is estimated from the size of the egg-form embryos (2-cell embryo to gastrula). Kaplan (1979) presented the conversion factors for each developmental stage for obtaining the initial egg size in Ambystoma tigrinum and $A$. maculatum. In the present study, the ontogenic increase in the size of egg-form embryos was examined in Hynobius nigrescens, as well as in H. lichenatus for comparison.

\section{MATERIALS AND Methods}

Eggs derived from 16 females of six populations of $H$. nigrescens, which were collected in breeding ponds at various altitudes in the Niigata area, were used as materials. For comparison, eggs derived from two females from a single population of $\boldsymbol{H}$. lichenatus were used. In every clutch, 15 fertilized eggs were artificially inseminated and drawn from the egg capsule, were placed individually in $10 \%$ Holtfreter's solution, and kept at $16^{\circ} \mathrm{C}$. The diameter of the egg-form embryos was measured, along two lines crossing at right angles, in each stage. For the determination of embryonic stages, the normal table for de-

Accepted 31, Oct. 1987 velopment in $H$. nigrescens (Usui and Hamasaki, 1939) was used. The measurement of embryos was done to the nearest $0.01 \mathrm{~mm}$ under a binocular microscope, and the average in each clutch was calculated for every developmental stage.

\section{Results ANd Discussion}

Table 1 shows the mean diameter of uncleaved eggs derived from each female and the characteristics of sampling sites. The range of the mean egg size was rather wide (from 2.37 to $3.06 \mathrm{~mm}$ ). However, the proportional increase in the size from the developmental stages up to gastrula did not significantly differ among the embryos of all the females examined (Friedman two-way analysis of variance). Fig. 1 shows the increases in the size of egg-form embryos with the advance of development in several females of $H$. nigrescens and $H$. lichenatus. In this figure, it can be seen that the trajectory forms of increasing embryo size were similar in $H$. nigrescens in spite of considerable variations in

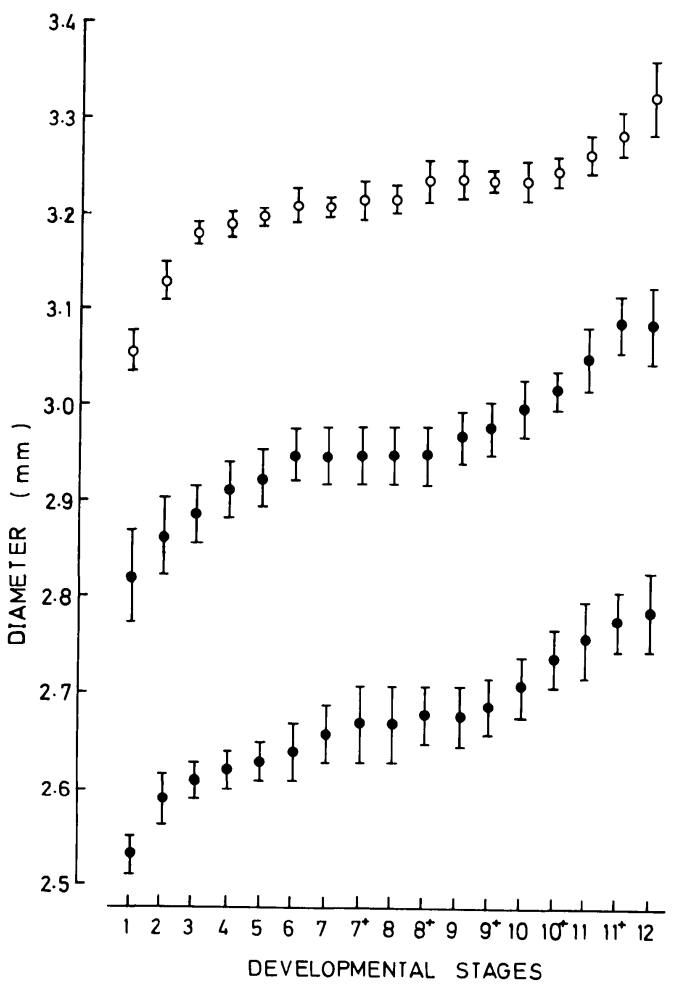

FIG. 1. Means (circles) and standard deviations (dashes) of the diameters of eggs and embryos derived from the females collected in Yahikojinjya-ike, Rintsuji-ike and Tagami-sawa. Solid circles: $H$. nigrescens, Open circles: $H$. lichenatus. 
TABLE 1. Sampling sites and averages of initial egg diameter for each female.

\begin{tabular}{|c|c|c|c|c|c|c|}
\hline \multirow{2}{*}{$\frac{\text { Sampling sites }}{\text { Hynobius nigrescens }}$} & \multirow[t]{2}{*}{ Locality } & \multirow[t]{2}{*}{$\begin{array}{c}\text { Altitude } \\
(\mathrm{m})\end{array}$} & $\begin{array}{c}\text { Date of } \\
\text { collection }\end{array}$ & \multicolumn{3}{|c|}{$\begin{array}{l}\text { Initial egg size } \\
(\mathrm{mm})\end{array}$} \\
\hline & & & & & & \\
\hline Rintsuji-ike & Yahiko-Mura & 40 & Mar. 10 & 2.82 & 2.47 & 2.56 \\
\hline Yahiko-jinjya-ike & Yahiko-Mura & 60 & Jan. 21 & 2.53 & 2.55 & - \\
\hline Shichiko-ike & Kakizaki-Machi & 520 & Apr. 21 & 2.67 & 2.67 & - \\
\hline Gaba-ido & Shitada-Mura & 630 & May 7 & 3.02 & 2.99 & 2.50 \\
\hline Nihondaira-san-ike & Mikawa-Mura & 650 & May 14 & 2.97 & 2.96 & 2.98 \\
\hline Wakakusa-ike & Shiozawa-Machi & 800 & May 19 & 2.37 & 2.47 & 2.39 \\
\hline \multicolumn{7}{|l|}{ H. lichenatus } \\
\hline Tagami-sawa & Tagami-Machi & 80 & May 24 & 2.82 & 3.06 & - \\
\hline
\end{tabular}

the initial egg size. Between $H$. nigrescens and $H$. lichenatus, it seems, however, that the trajectory form of embryonic size differs somewhat, particularly in earlier developmental stages. Although no statistical difference is found between $H$. nigrescens and $H$. lichenatus, it is estimated that the proportional increases in

TABLE 2. Conversion factors for calculating initial egg diameter from the diameter of egg-form embryos

\begin{tabular}{clc}
\hline $\begin{array}{c}\text { Normal } \\
\text { stage* }\end{array}$ & \multicolumn{1}{c}{$\begin{array}{c}\text { Description } \\
\text { of stage }\end{array}$} & $\begin{array}{c}\text { Conversion } \\
\text { factors }\end{array}$ \\
\hline 1 & Uncleaved & 1.00 \\
2 & 2-cell & 0.98 \\
3 & 4-cell & 0.97 \\
4 & 8-cell & 0.96 \\
5 & 16-cell & 0.96 \\
6 & 32-cell & 0.95 \\
7 & Morula & 0.95 \\
$7^{+}$ & Late morula & 0.94 \\
8 & Early blastula & 0.94 \\
$8^{+}$ & Early blastula & 0.94 \\
9 & Mid blastula & 0.93 \\
$9^{+}$ & Mid blastula & 0.93 \\
10 & Late blastula & 0.92 \\
$10^{+}$ & Appearance of blastoporic lip & 0.91 \\
11 & Crescent blastoporic lip & 0.90 \\
12 & Yolk plug & 0.90 \\
\hline
\end{tabular}

* Usui and Hamasaki (1939) size between stages differ somewhat between these two species. In addition, the trajectory form of increasing embryonic size in $H$. nigrescens differs slightly from the results reported in Ambystoma (Kaplan, 1979).

The conversion factors for $H$. nigrescens by which embryonic size should be multiplied in order to obtain the initial egg size are presented in Table 2. It seems that these conversion factors are uniformly useful in $H$. nigrescens. It may be possible to use them practically for $H$. lichenatus also, except in the earlier developmental stages.

\section{Literature Cited}

KAPLAN, R. H. 1979. Ontogenetic variation in "ovum" size in two species of Ambystoma. Copeia 1979(2): 348-350.

LøVtrup, S. 1960. Water permeation in the amphibian embryo. J. Exp. Zool. 145(2): 139149.

Usui, M. AND M. Hamasaki. 1939. Tafeln zur Fntwicklungsgeschichte von Hynobius nigrescens Stejneger. Zool. Mag. (Tokyo) 51(4): 195-206. (in Japanese)

Biological Institute, Faculty of Science, Niigata University, Niigata, 950-21 JAPAN 


\section{要旨 クロサンショウウオ Hynobius nigres-}

cens の球状胚の発生にともなう大きさ の变化

高橋 久・岩沢久彰 を調べた。受精卵の大きさは直径 $2.37 \mathrm{~mm}$ か 両生類の卵は発生の進行と共に大きさを増す。ら $3.06 \mathrm{~mm}$ までと大きく異なったが，ステー よって, 卵サイズを正確に知るためには受精直 後の未分割卵を用いることが求められるが，野 外で受精直後の卵を採集することは必ずしも容 易でない。そのため比較的に採集の容易な球状 胚の大きさから産出直後の未分割卵の大きさを 算出する方法を検討した。標高 $40 〜 800 \mathrm{~m}$ の 産卵池から採集したクロサンショウウオの雌 16 個体に由来する卵，および比較のためにトゥホ クサンショウウオの雌 2 個体に由来する卵を用 いて, 囊胚期までの胚の発生に伴う直径の変化 ジ間の直径の増加の割合は, 全ての雌由来の卵 の間で有意な違いはみられなかった。しかし， クロサンショウウオとトウホクサンショウウオ の間には，ごく初期のステージにおいて，サイ ズの増加の割合に多少の違いがみられた。各ス テージの胚の直径から未分割卵の直径を算出す るための係数を示した。

（950-21 新潟市五十嵐 新潟大学理学部生物 学教室) 